\title{
Exploring Organisational Citizenship Behaviour through the Lens of Age
}

\author{
Silvia Profili ${ }^{1}$, Alessia Sammarra ${ }^{2} \&$ Laura Innocenti $^{3}$ \\ ${ }^{1}$ European University of Rome, Rome, Italy \\ ${ }^{2}$ University of L'Aquila, L'Aquila, Italy \\ ${ }^{3}$ LUISS Business School, Rome, Italy \\ Correspondence: Silvia Profili, European University of Rome, Viale degli Aldobrandeschi 190, 00163, Rome, Italy. \\ Tel: 39-6-665-431.
}

Received: November 17, 2016

Accepted: December 5, $2016 \quad$ Online Published: December 19, 2016

doi:10.5430/ijba.v8n1p22

URL: http://dx.doi.org/10.5430/ijba.v8n1p22

\begin{abstract}
This paper sheds light on the mechanisms through which age diversity climate affects employees' positive attitudes and behaviours. Specifically, the study examines: a) the mediating role of affective commitment in the relationship between age diversity climate and organisational citizenship behaviour, and b) the moderating effect of employees' focus on future occupational opportunities on the link between age diversity climate and affective commitment. Applying regression analyses to a sample of 326 employees from a multinational pharmaceutical company, we found that affective commitment fully mediates the relationship between perceived age diversity climate and organisational citizenship behaviour. Furthermore, the results revealed that employees' focus on opportunities is negatively correlated with their chronological age and positively correlated with affective commitment. However, contrary to our hypothesis, employees' focus on opportunities did not moderate the link between age diversity climate and affective commitment. The results have implications for both theory and practice, suggesting that endeavours to maintain and sustain an inclusive age diversity climate should be regarded as critical.
\end{abstract}

Keywords: age diversity climate, affective commitment, organisational citizenship behaviour, focus on opportunities, age

\section{Introduction}

Due to ongoing social and demographic transformations that are affecting all Western countries, the workforce is not only becoming older, but more age-diverse. These demographic shifts compel organisations to attract, retain and motivate employees at any age by ensuring a positive age diversity climate.

A look at the literature on age diversity, though, reveals a prominent focus on older workers. Butler (1969) coined the concept of ageism to refer to the "process of systematic stereotyping and discrimination against people because they are old" (p. 22). Drawing on this concept, several studies have pointed out that age discrimination, or at least unfair treatment, is likely to occur for older workers, especially when they are relatively older than other colleagues in their group or their manager (Shore, Chung-Herrera, Dean et al., 2009). Meanwhile, older employees are likely disadvantaged when it comes to important human resource management decisions: For instance, Finkelstein et al. (1995) found that when older and younger applicants appear in the same applicant pool, the latter are preferred over the former. Previous studies also found that older workers tend to receive fewer opportunities for training and development (Loretto \& White, 2006; Maurer \& Rafuse, 2001), lower assessments of promotability (Shore, Cleveland, \& Goldberg, 2003), and harsher consequences for lower performance (Rupp, Ganapathi, Aguilera et al., 2006). According to Innocenti, Profili, and Sammarra (2013), HR development practices are less able to positively impact job satisfaction and affective commitment as employees get older. Studies on career progression have also noted a decrease in upward mobility with age (Cox \& Nkomo, 1992).

However, research on age diversity and discrimination has gained more consideration in recent years, leading to new lines of inquiry. While the focus on older workers remains predominant, researchers have begun extending the concept of ageism to encompass potential prejudices and subsequent discrimination against any age group (Kunze, Boehm, \& Bruch, 2011). In their study of a local authority, for instance, Snape and Redman (2003) found that discrimination on the grounds of being 'too young' is at least as common as discrimination on the grounds of being 'too old'. 
Moreover, recent research has started to explore the outcomes of perceived and actual age discrimination on employees' attitudes and organisational performance. Focusing on the organisational level of analysis, Kunze, Boehm, and Bruch (2011) found a negative relationship between an organisation's perceived age discrimination climate and organisational performance, mediated by employees' collective affective commitment. Focusing on the individual level of analysis, Rabl and Triana (2013) explored the link between perceived age discrimination and affective commitment. They found a negative relationship that was stronger for older employees than for younger employees.

Following this lead, the present paper aims to contribute to this stream of research in two ways. First, it examines the effects of age diversity climate beyond employees' positive attitudes by focusing on organisational citizenship behaviour (OCB). According to Mamman, Kamoche, and Bakuwa (2012), "OCB is more vulnerable to the consequences of injustice or perception of injustice than are behaviours that are in role and explicitly defined in the contract of employment" (p. 287). Therefore, we assume that employees' perceptions of a positive age diversity climate have an impact on their affective commitment, which in turn affects their discretionary behaviours.

Second, the research so far has focused on chronological age as a possible moderating factor in the relationship between perceptions of age climate/age discrimination and affective commitment (Rabl \& Triana, 2013), but this fails to capture the subjective dimension of the ageing process. Some authors suggested that we should start considering individuals' biological, psychological and social evolution as it relates to age instead of seeing chronological age as a factor in itself (Kooij, de Lange, Jansen, et al., 2013; Griffiths, 1997). As a matter of fact, people frequently perceive themselves as being an age other than their birth age, and this self-perceived age seems to influence their attitudes and behaviours.

Recent research has demonstrated that individuals' perceptions of their remaining professional opportunities constitute an important subjective dimension related to the ageing process. Having proposed 'focus on opportunities' as a construct, Zacher, Heusner, Schmitz, et al. (2010) showed that it mediates the relationship between chronological age and work performance. Building on these initial findings, this paper introduces and tests this very construct as a moderator in the relationship between perceived age diversity climate and affective commitment.

The paper is structured as follows: First, we outline the theoretical background and develop our hypotheses. Second, we describe the methodological design of our study. Third, we present and discuss the results. Finally, we highlight the study's implications for theory, managerial practice and future research.

\section{Theoretical Framework and Hypothesis Development}

The demographic changes occurring in many industrialized countries imply a need to examine age-related issues in the workplace. Forecasts suggest that the number of young workers in the Western world will decrease while the number of older workers will substantially increase (European Commission, 2005). The populations of Western countries are significantly ageing, which implies a remarkable incidence of workers over the age of 50 (OECD, 2006). Subsequently, organisations need to adapt their policies to the expectations and abilities of older workers. To be able to attract and retain talent from all age groups, organisations have to effectively signal that their employees are seen as a strategic and essential resource regardless of their age (Mor Barak, Cherin, \& Berkman, 1998). To do so requires creating an organisational climate that pursues inclusion over discrimination.

An extensive body of research on organisational climate has examined how individuals respond to their work environment based on their appraisal of the work context (James \& James, 1989). Indeed, it seems that positive perceptions of a work environment can significantly impact employees' attitudes and behaviours (Carr, Schmidt, Ford, et al., 2003; Parker, Baltes, Young et al., 2003).

Climate has been conceptualized as a general or facet-specific construct. As noted by Carr et al. (2003), general climate refers to employees' perceptions of their work environment as a whole-including, for example, their perceptions of the way they are treated and rewarded by the organisation and its representatives, and the extent to which the work environment is generally supportive of their well-being. Facet-specific climate refers to narrower aspects of the work environment, such as climates for innovation (Abbey \& Dickson, 1983), service (Schneider, Salvaggio, \& Subirats, 2002), safety (Zohar, 2000) and diversity climate (McKay, Avery, \& Morris, 2009). McKay and colleagues (2009) defined diversity climate as employees' shared perceptions about the extent to which their organisation values diversity by utilizing fair practices and socially integrating all personnel.

Several studies have focused on the effects of diversity climate on individuals' positive attitudes (Buttner, Lowe, \& Billings-Harris, 2012; Gonzalez \& DeNisi, 2009) as well as organisational outcomes (McKay, Avery, Tonidandel et al., 2007). They show that when people do not feel marginalized and excluded because of their ties to an 
underrepresented group, they are more motivated and more likely to contribute to organisational functioning (Roberson \& Block, 2001). However, only a few studies have examined distinct and specific forms of diversity climate perceptions, and the majority of them have focused on race and gender discrimination. Considering that demographic trends point to increasing age diversity in the workplace, it is likely that age diversity climate will become a more important factor that influences employees' appraisal of their work environment. Therefore, researchers and organisations need more insight into how age diversity climate perceptions impact employees' attitudes towards the organisation - starting with a specific age-related measure of climate instead of a general measure of diversity climate (Boehm, Kunze \& Bruch, 2014; Schneider, Ehrhart, \& Macey, 2011). Boehm, Kunze and Bruch (2014) defined age diversity climate as "organisational members' shared perceptions of the fair and nondiscriminatory treatment of employees of all age groups with regard to all relevant organisational practices, policies, procedures, and rewards" (p. 5). Employees who perceive a pronounced age diversity climate do not feel discriminated against because of their age; they also see their organisation as promoting behaviours that are age-neutral toward both older and younger employees.

So far, there has been scant research into the consequences of age diversity climate on individual and organisational outcomes. Kunze, Boehm and Bruch (2011) found that an increasingly age-discriminating climate leads to decreased levels of collective affective commitment, which then negatively affect company performance. Perceived discrimination on the basis of age has also been associated with reduced job and life satisfaction, job involvement, and perceived power and prestige on the job (Hassell \& Perrewé, 1995; Orpen, 1995; Redman \& Snape, 2006). Redman and Snape also showed that discrimination against older workers leaves them feeling less affectively committed to the organisation and they also feel that they are 'locked in', perhaps due to perceived disadvantage in the labour market (2003: 86). Recently, Boehm, Kunze and Bruch (2014) found that age diversity climate is an important mediator in the relationship between age-inclusive HR practices and firm performance.

Following from this basis, the present study aims to study the impact of age diversity climate on employees' attitudes and behaviours. In doing so, we extend previous research in two ways. First, we provide an empirical validation of the age diversity climate and, in contrast to Kunze and colleagues (2011), measure this specific form of diversity climate as an individual-level construct. Second, we shed light on the mechanisms through which age diversity climate affects positive attitudes and behaviours, specifically by examining: a) the moderation effect of individuals' perceptions of their future opportunities, and b) the mediating role of affective commitment in the relationship between OCB and perceptions of age diversity climate.

\subsection{Age Diversity Climate and Organisational Citizenship Behaviour}

The interest in work behaviours that exceed the duties of a job position stems from the work of Katz (1964). According to the author, employees' behaviour can follow this three-stage path: Firstly, individuals must be induced to enter and remain with an organisation; secondly, they must carry out the activities related to their specific role requirements, and finally, they must engage in innovative and spontaneous activities that go beyond role prescriptions. Among these extra-role behaviours, organisational citizenship behaviour (OCB) has been widely analysed in recent decades due to its impact on the effectiveness and efficiency of both work teams and individual performance (Organ, 1989). Although extra-role behaviours cannot be called core task activities per se (Organ, 1989), they can influence organisational productivity by shaping the organisational cultures and contexts in which core task performance takes place (Borman \& Motowidlo, 1997).

Citizenship behaviour is defined as a behaviour above and beyond the call of duty and therefore not directly or explicitly recognized by the formal reward system (Konovsky \& Pugh, 1994). This type of behaviour refers to the additional things people do at work that are beneficial to the organisation, but are not predictably enforceable by supervisors or a job description. The extant literature defines OCB as a multi-dimensional construct. The most established taxonomy, proposed by Organ (1989), includes five behavioural dimensions: altruism, courtesy, conscientiousness, sportsmanship, and civic virtue.

Although much of the empirical literature has focused on Organ's (1989) five-dimension framework, other studies have focused on specific OCB dimensions in isolation (LePine \& Van Dyne, 1998; 2001). The present study follows this approach by focusing on employees' altruistic behaviour towards co-workers (e.g., helping others who have been absent or have heavy workloads, taking on non-required tasks, and orienting new people when it is not required). We focus on altruism because organisations are shifting away from the use of hierarchical structures and individualized jobs in favour of autonomous team-based structures that increase flexibility, knowledge sharing, creativity, and innovation. Altruism is the most crucial of the five dimensions to the success of this new paradigm. 
A substantial amount of research has been devoted to understanding the motivational bases of OCB. One set of studies explains this extra-role behaviour as a form of employee reciprocity. That is, employees engage in OCB to respond to good or fair treatment they have received from co-workers, supervisors or the organisation (Organ, 1990). The link between employees' positive behaviours towards the firm and their experiences in the workplace is therefore explained by social exchange theory (Blau, 1964; Gouldner, 1960). In other words, the positive conditions promoted by the organisation (i.e., satisfying work assignments, supportive managers, fair treatment by employers) motivate the individual to reciprocate through discretionary behaviour that benefits the organisation.

A pronounced age diversity climate is a key condition in whether employees generate shared feelings of working toward common goals, as well as perceive the organisation as fair, trustworthy, caring, and long-term orientated. Thus, such a climate should foster a high-quality social exchange relationship between employees and the organisation, and is hence associated with a higher level of OCB (Wayne, Shore, \& Liden, 1997). Perceived inclusiveness facilitates feelings of obligation and trust, which encourage employees to reciprocate inclusive attitudes and behaviours in the form of organisational citizenship behaviours and organisational commitment (Shore et al., 2011). On the contrary, the perception of a weak age diversity climate may be viewed as a violation of the norm of reciprocity (Gouldner, 1960), which is a precondition for employees' positive attitudes towards the organisation.

Based on this theoretical and empirical evidence, we hypothesize that:

Hypothesis $1-A$ high age diversity climate is positively related to $O C B$

\subsection{Affective Commitment as a Mediator between Age Diversity Climate and OCB}

Organisational commitment is a multidimensional variable that expresses employees' degree of identification with their employer, their attachment to their organisation, and their willingness to expend effort on the organisation's behalf (Mowday et al., 1979). Meyer and Allen (1991) propose a conceptualization of commitment that comprises three components, each of which reflects a unique underlying psychological state. Affective commitment refers to employees' emotional attachment to the organisation, such that they continue their employment because they want to do so. Continuance commitment captures employees' awareness of the costs associated with leaving the organisation; in other words, it reflects employees' intent to remain because they need to do so. Finally, normative commitment is associated with a feeling of obligation, whereby employees feel that they ought to remain with the organisation. Of these three traditional components, we join most recent research in focusing on the first. As Meyer and Allen (1997) assert, affective commitment predominates in research because it is more closely related to desirable behavioural outcomes such as staying in the organisation and engaging in both in-role and discretionary effort at work (Shore et al., 1995).

Several theoretical perspectives suggest a relationship between perceived age diversity climate and affective commitment. The social exchange and organisational support theory frameworks (Meyer \& Allen, 1997; Rhoades \& Eisenberger, 2002) postulate that perceived favourable treatment and positive experiences at the workplace create a generalized sense of indebtedness to the organisation, which fosters employees' affective reactions at work. As said before, the perception of a low age diversity climate may be viewed as a violation of the norm of reciprocity (Gouldner, 1960), and thereby hinder employees' positive attitudes towards the organisation.

Another theoretical framework that supports a positive link between perceived age diversity climate and affective commitment is conservation of resources (COR) theory (Hobfoll, 1989; 2001). In this framework, employees who perceive a low age climate may feel that discrimination represents a loss of important resources such as 'recognition for their accomplishment and value' and 'feeling valuable for others.' They will then react to the psychological stress resulting from this perceived loss by minimizing their level of affective commitment (Rabl \& Triana, 2013).

There is also empirical support for the relationship between age diversity climate and affective commitment. Snape and Redman (2003) found that employees who perceive age discrimination in their organisation have a lower level of affective commitment. Similarly, Hassel and Perrewé (1993) found a negative relationship between employees' perceptions of age discrimination and self-esteem and general satisfaction. Kunze et al. (2011) argued that perceived age discrimination climate has a negative effect on the collective affective commitment within companies, which can negatively impact company performance.

Based on these considerations, we expect that perceived age diversity climate influences employees' affective commitment. Specifically, we expect that employees may exhibit a higher level of affective commitment when they perceive the organisation as an inclusive work environment towards any age group.

Hypothesis 2 - A high age diversity climate is positively related to affective commitment 
This paper advances an analytical framework that positions affective commitment as a mediator in the relationship between age diversity climate and OCB. Most scholars agree that employees with strong affective commitment are more willing to engage in OCB than those with weak affective commitment. Numerous studies have found support for this relation across both self-reports and independent assessments of behaviour (Meyer \& Allen, 1997). According to Mamman et al. (2012), organisational commitment is a significant mediator of OCB because "as a cognitive construct, it allows the employees to think and process their experience before reacting" (p. 294). In particular, Pare and Trembley (2007) found a significant and positive relationship between affective commitment and the helping dimension of OCB. Meanwhile, McKay et al. (2007) found that the relationship between diversity climate and turnover intentions is mediated by organisational commitment.

On the basis of these considerations, we posit that there is a positive relation between age diversity climate and OCB that will be mediated by affective commitment. Formally:

Hypothesis 3 - Affective commitment is positively related to $O C B$

Hypothesis 4 - The age diversity climate-OCB positive relation is mediated by affective commitment

\subsection{The Moderation Effect of Focus on Opportunities}

Most studies on age in the workplace have proposed a chronological conceptualization of age, failing to capture other age-related variables that may better explain how psychological ageing contributes to positive attitudes and organisational behaviour.

According to Kooji et al. (2013), chronological ageing is only one sub-process of a more complex process of ageing. Employees with the same chronological age may differ in terms of their job tenure, health, family status, and meaning they assign to age (Cleveland \& Shore, 1992; Settersten \& Mayer, 1997). In light of this, several authors have proposed different conceptualizations of age that differentiate from biological age, such as subjective age, health status, relative age, and future time perspective. 'Subjective age' refers to how old individuals feel, look and act, with which age cohort they identify, and how old they desire to be (Kaliterna et al., 2002). This measure is important, as most people perceive themselves as younger or older than their chronological age and this disparity may influence individuals' attitudes and behaviours (Van Auken \& Barry, 2009). Meanwhile, 'general health status' captures the age-related losses in both physical and cognitive abilities and can be particularly relevant for older workers (Kooji et al., 2013). In terms of relative age, this perspective argues that working with colleagues who have a different age may produce social isolation, which may in turn negatively affect positive attitudes towards the work environment (Cleveland \& Shore, 1992).

The final conceptualization, the future time perspective (FTP), describes individuals' sense of how much time they have left in their future and how they perceive that time (Cate \& John, 2007). This concept is particularly important in the wake of rising life expectancy and changes in retirement plans, which together are increasing people's working time. For instance, Kooij et al. (2013) found that subjective health and future time perspective have a mediation effect on the relation between age and work-related motivations.

Taking a different approach, Zacher and colleagues (2010) adapted the concept of focus on opportunities as a cognitive-motivational facet of occupational FTP; in this way, they sought to capture how many new goals, options, and possibilities individuals expect to have in their personal work-related futures. The authors demonstrated that a focus on opportunities, although negatively related to chronological age, mediates the relationship between age and work performance.

Our contribution to this stream of research is twofold. First, our study aims to provide empirical evidence of the important role that employees' focus on opportunity plays in the development of their positive attitudes and behaviours. More precisely, we include focus on opportunity as a moderating variable in the positive link between age diversity climate and affective commitment. Previous research has demonstrated that particularly positive beliefs about the future lead to higher motivation and successful performance because they promote individual well-being, successful problem-solving, the setting of high standards, and persistence in goal pursuit (Aspinwall, 2005; Oettingen \& Mayer, 2002; Peterson, 2000). Accordingly, a focus on opportunities represents a form of positive thinking about the future that is potentially important for motivation and successful performance (Cate \& John, 2007). Drawing on these suggestions, we expect that the positive relationship between age diversity climate and affective commitment will be stronger for those who have a stronger focus on opportunities. According to Markus and Nurius (1986), "the meaning given to a particular self-relevant event depends on the context of possibility that surrounds it" (p. 926). In other words, individuals judge their current actions and situations according to their perceived future possibilities. Employees who believe that they have many new goals, options, and possibilities in their personal future probably tend to appreciate an organisational context that is fair and open regardless of age, as it will provide 
them with better conditions to fulfil their goals. These factors should in turn lead to a higher level of affective commitment.

Hypothesis 5 - Focus on opportunities moderates the positive relationship between age diversity climate and affective commitment in such way that this relationship is stronger when focus on opportunities is high.

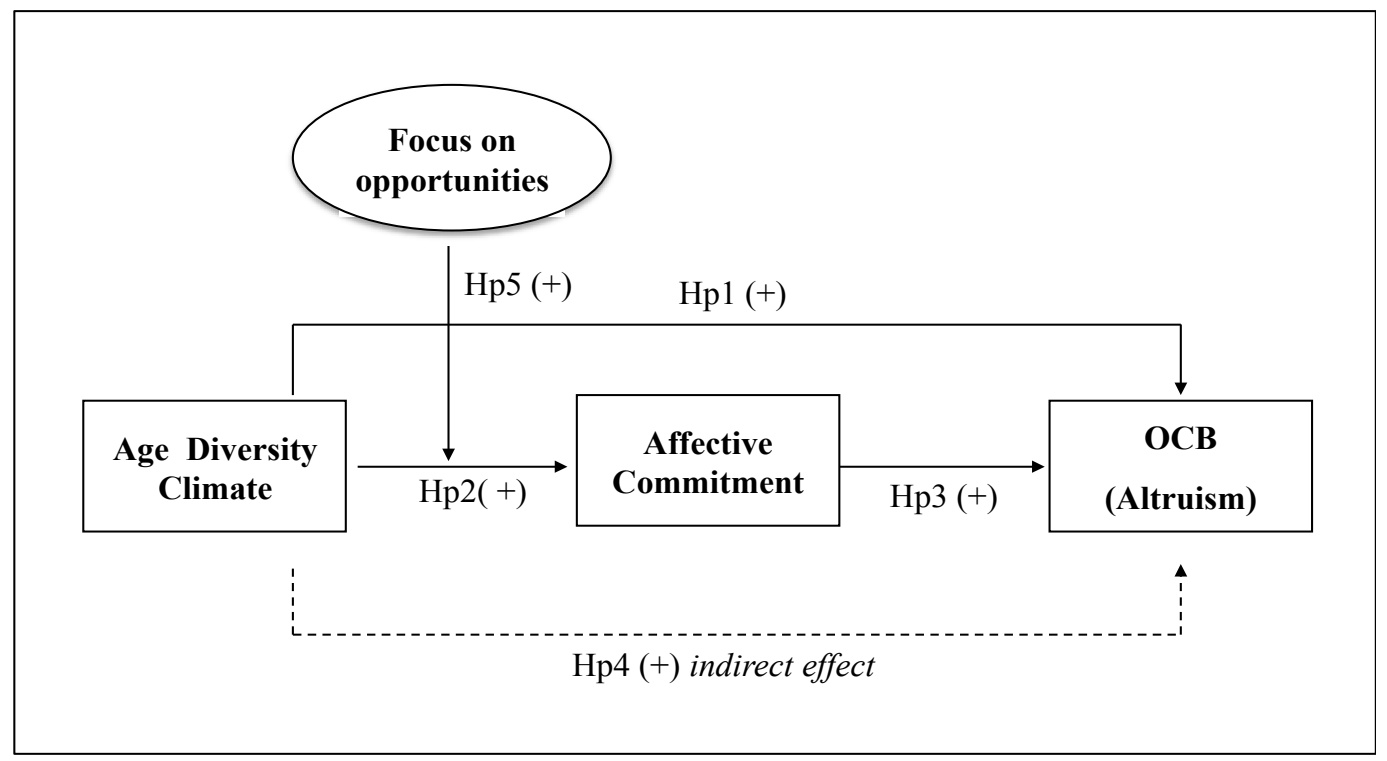

Figure 1. Theoretical model for the relationship between age diversity climate and organisational citizenship behaviour (OCB)

\section{Method}

We collected data from the Italian branch of a large multinational pharmaceutical company. We distributed a structured survey online to a sample of 430 employees, who came from different organisational functions and roles. 364 employees (85\%) responded to the on line survey. After deleting cases with missing values, we retained 326 respondents for the analyses. Men and women comprised $52 \%$ and $48 \%$ of the sample, respectively, and the mean age was 47 years $(\mathrm{SD}=8.29)$.

\subsection{Measures}

To measure the constructs in the proposed model, we assessed all scale items on a five-point Likert scale ranging from 1 (almost always not true) to 5 (almost always true).

Table 1. Descriptive statistics, correlations, and scale reliabilities for variables

\begin{tabular}{|c|c|c|c|c|c|c|c|c|c|}
\hline & Alpha & Mean & SD & 1 & 2 & 3 & 4 & 5 & 6 \\
\hline 1 Age & & 46.64 & 8.29 & & & & & & \\
\hline 2 Gender & & & & $-.379 * *$ & & & & & \\
\hline 3 Role & & & & $.166^{* *}$ & $-.222 * *$ & & & & \\
\hline $\begin{array}{l}4 \text { Age diversity } \\
\text { climate }\end{array}$ & .839 & 3.51 & 0.67 & -.098 & -.061 & .053 & & & \\
\hline $\begin{array}{l}5 \text { Focus on } \\
\text { opportunities }\end{array}$ & .810 & 3.01 & 0.97 & $-.243 * *$ & -.015 & $.131 *$ & $.542 * *$ & & \\
\hline $\begin{array}{l}6 \text { Affective } \\
\text { commitment }\end{array}$ & .722 & 3.83 & 0.60 & $.152 * *$ & -.066 & .077 & $.547 * *$ & $.357 * *$ & \\
\hline $\begin{array}{l}7 \text { OCB } \\
\text { (Altruism) }\end{array}$ & .712 & 4.06 & 0.46 & -.058 & .025 & .005 & $.161 * *$ & $.164 * *$ & $.249 * *$ \\
\hline
\end{tabular}

Notes: $* \mathrm{p}<.05, * * \mathrm{p}<.01$. 
Table 1 highlights the scales' reliabilities, means, standard deviations and interrcorrelations for each variable.

Affective Commitment: We measured affective commitment using five items from the scale developed by Allen and Meyer (1996). Sample items included: "I really feel as if these organisation's problems are my own" and "I feel like "part of the family" at my organisation".

Organisational Citizenship Behaviour (Altruism): We focused on the altruism dimension of OCB by adopting four items from Podsakoff et al.'s (1990) scale. Sample items included: "I willingly help others who have work related problems" and "I help others who have heavy workloads".

Focus on Opportunities: This was assessed with three self-report items adopted from Zacher et al.'s (2010) scale. Sample items included: "My occupational future is filled with possibilities" and "There are only limited possibilities in my occupational future" (reverse coded).

Age Diversity Climate: We focused on the individual level of analysis, investigating the psychological (rather than the collective) perceptions of the age diversity climate. The psychological age-diversity climate is defined as employees' individual perceptions that organisational practices and policies are fair towards all age groups and socially integrate all organisational members regardless of their age. To this end, we used a five-item measure adapted from McKay et al.'s (2009) general diversity climate scale. Sample items included: "I trust the organisation to treat fairly people of my age" and "The organisation respects the views of people of my age".

We also included chronological age, gender $(1=$ male; $2=$ female $)$ and job position as control variables. Job position was measured with a three-point scale: "employee" $(28 \%)$, "middle manager" $(62 \%)$ and "manager" $(10 \%)$.

CFAs were conducted to assess the study measures' factor structure in Amos 19.0 (Arbuckle, 2006). The measurement model consisted of four latent constructs: age-diversity climate, focus on opportunities, affective commitment, and organizational citizenship behavior, measured with 17 items overall. All items loaded significantly on their latent factor with factor loadings largely above .40, which is a threshold often applied in factor analysis (Hulland, 1999). The model provided an acceptable fit for our data (RMSEA $=.063$, CFI $=.87$, IFI $=.90$ ). We compared the measurement model to three alternative more parsimonious models in order to test for the discriminatory validity of our measures. In no case did an alternative model fit the data as well as the hypothesized model. First, to inspect the distinctiveness of the age diversity climate and focus on opportunity measures we analyzed a three-factor model in which the age-diversity climate and focus on opportunity items loaded on one common factor. This alternative model had a worse fit $(\mathrm{RMSEA}=.071, \mathrm{CFI}=.80, \mathrm{TLI}=.81)$, indicating that it is possible to discriminate between these constructs. Second, we compared the fit of the data to a three-factor model in which affective commitment and OCB items loaded on one common factor $($ RMSEA $=.071$, CFI $=.81, \mathrm{TLI}=.80)$. Finally, we analyzed a one-factor model with all items loading on one common factor (RMSEA $=.12, \mathrm{CFI}=.63$, $\mathrm{TLI}=.61)$. The fit indices of the different models show that the four-factor model fits the data significantly better than the other models.

\section{Analysis and Results}

We used hierarchical multiple regressions to test hypotheses 1,2,3, and 4, and hierarchical moderated regression to test hypothesis 5. In all analyses, we entered age, gender and two dummy variables that represented employees' organisational role. We standardized all continuous variables to test the interaction effect, as well as reduce the likelihood of multicollinearity influencing our results (Van Aiken \& West, 1991). Next, we tested for mediation following the three-stage analysis procedure recommended by Baron and Kenny (1986).

Table 2. Results of mediation analysis

\begin{tabular}{lllll}
\hline & & \multicolumn{2}{c}{ OCB (Altruism) } \\
\hline Variables & $\begin{array}{l}\text { Affective } \\
\text { commitment }\end{array}$ & Step 1 & Step 2 & Step 3 \\
\hline Gender & .061 & .019 & .020 & .020 \\
\hline Age & $.242^{* *}$ & -.032 & -.098 & -.087 \\
\hline Employee & -.030 & -.002 & .006 & .007 \\
\hline Middle manager & -.008 & -.024 & .026 & .029 \\
\hline Age diversity climate & $.580^{* *}$ & $.165^{* *}$ & & .030 \\
\hline Affective commitment & & & $.277^{* *}$ & $.257^{* *}$ \\
\hline $\boldsymbol{F}$-statistic & $32.90^{* *}$ & 1.933 & $5.207^{* *}$ & $4.221^{* *}$ \\
\hline $\boldsymbol{R}^{2}\left(\right.$ Adj. $\left.\boldsymbol{R}^{2}\right)$ & .344 & .015 & .064 & .060 \\
\hline
\end{tabular}

Notes: $* \mathrm{p}<.05, * * \mathrm{p}<.01$. 
Table 2 shows that the direct relationship between the age diversity climate and altruism was, as expected, positive and significant $(\beta=.165 \mathrm{p}<.01)$, confirming hypothesis 1 . The results of the regressions show that age diversity climate was positively related to affective commitment $(\beta=.580, \mathrm{p}<.01)$, confirming hypothesis 2 , and that affective commitment had a positive effect on altruism $(\beta=.277, \mathrm{p}<.01)$, confirming hypothesis 3 . Finally, when we entered both age diversity climate and affective commitment into the model simultaneously, significance levels decreased. Thus, it appears that affective commitment fully mediates the relationship between age diversity climate and altruism, as predicted by hypothesis 4 .

Table 3. Results of moderation analysis

\begin{tabular}{llll}
\hline Variables & Step 1 & Step 2 & Step 3 \\
\hline Gender & -.001 & .068 & .064 \\
\hline Age & $.147^{*}$ & $.276^{* *}$ & $.276^{* *}$ \\
\hline Employee & -.063 & .011 & .007 \\
\hline Middle manager & .002 & .024 & .021 \\
\hline Age diversity climate & & $.497^{* *}$ & $.496^{* *}$ \\
\hline Focus on opportunities & & $.157^{* *}$ & $.147^{* *}$ \\
\hline Age diversity climate $\boldsymbol{x}$ & & & .047 \\
Focus on Opportunities & & &
\end{tabular}

\begin{tabular}{llll}
\hline $\boldsymbol{F}$-statistic & 2.220 & $29.212^{* *}$ & $25.192^{* *}$ \\
\hline $\boldsymbol{R}^{2}\left(\boldsymbol{A d j} . \boldsymbol{R}^{\mathbf{2}}\right)$ & .016 & .358 & .358 \\
\hline
\end{tabular}

Notes: $* \mathrm{p}<.05,{ }^{* *} \mathrm{p}<.01$.

Table 3 displays the results of the moderation analysis. As can be seen, focus on opportunities did not interact with age diversity climate to predict affective commitment. Therefore, hypothesis 5 was not supported.

\section{Theoretical Contributions and Managerial Implications}

Although there has been extensive research on employees' positive attitudes and behaviour, there is still a lack of knowledge concerning these dimensions and their relationship with age diversity. Previous studies (Kunze, Boehm \& Bruch, 2011; Rabl \& Triana, 2013) have hypothesized and found that perceived age discrimination negatively affects employees' affective commitment. Our study corroborates and expands these initial findings in two ways. First, we demonstrate that age diversity climate affects not only employees' attitudes, but also their work behaviour. In line with our hypothesis, perceptions of an age-inclusive context were positively related to the extent to which employees voluntarily help others manage or prevent work-related problems. Second, we were able to illuminate the mechanisms that influence the link between age diversity climate and altruism by establishing affective commitment as a mediator for this relationship.

We did not find support for the hypothesized moderation effect of focus on opportunities on the relationship between age diversity climate and affective commitment; the interaction, although positive, was not significant. However, the results from the descriptive analyses showed that focus on opportunities was positively and significantly correlated with both affective commitment and age diversity climate and negatively with age. These results confirm previous research that showed that the focus on opportunities declines with age (Cate \& John, 2007; Zacher \& Frese, 2009), but also provide empirical evidence that one's focus on opportunities is positively associated with important work-related attitudes. Ultimately, our study joins previous research (Kooij et al., 2013) in suggesting that age diversity in the workplace requires more investigation - particularly with regard to age-related dimensions, such as focus on opportunities, that may influence employees' attitudes and behaviour more directly than chronological age.

This study also contributes to the extant literature on diversity in the workplace. The impact of age diversity climate on employees' positive attitudes and behaviours demonstrates that ageism may have relevant negative outcomes. Thus, research on age discrimination, while much less developed than that on race and gender, deserves further consideration from the diversity literature.

In terms of managerial implications, our findings highlight the crucial role of a positive age climate in terms of sustaining employees' commitment and altruism. Consequently, organisations should undertake greater efforts to create an inclusive and fair work environment for all age groups. 
Of course, the paper has some limitations that need to be acknowledged. First, the study is cross-sectional and this limits the conclusions that can be made regarding the cause-effect relationships. Future studies might overcome this weakness by applying longitudinal or experimental research designs. Second, our study is mostly based on self-report measures, which raises the possibility of common method bias. However, there are two reasons why we are confident that common method variance poses little threat to the validity of our findings. First, we created temporal and psychological separations in our survey by locating the items of the scales measuring the key constructs non-consecutively (Podsakoff et al., 2012). Second, whereas common method variance concerns may be relevant for main effects, they are less likely to apply to interaction effects. Another limitation of the present study concerns the generalizability of our findings because the data came from only one organisation. Although the sample was representative of different age cohorts, genders and work roles, future research could benefit from testing the same model in different contexts.

\section{References}

Abbey, A., \& Dickson, J.W. (1983). R\&D work climate and innovation in semiconductors. Academy of Management Journal, 26, 362-368. https://doi.org/10.2307/255984

Allen, N.J., \& Meyer, J.P. (1996). Affective, continuance, and normative commitment to the organization: An examination of construct validity. Journal of Vocational Behavior, 49(3), 252-276. https://doi.org/10.1006/jvbe.1996.0043

Arbuckle, J.L. (2006). AMOS (Computer Software). AMOS Development Cooperation, Spring House, PA.

Aspinwall, L.G. (2005). The psychology of future-oriented thinking: From achievement to proactive coping, adaptation, and aging. Motivation and Emotion, 29, 203-235. https://doi.org/10.1007/s11031-006-9013-1

Baron, R., \& Kenny, D. (1986). The moderator-mediator variable distinction in social psychological research: Conceptual, strategic and statistical considerations. Journal of Personality and Social Psychology, 51, 1173-82.

Benson, J., \& Brown, M. (2011). Generations at work: are there differences and do they matter?. The International Journal of Human Resource Management, 22(9), 1843-1865. https://doi.org/10.1080/09585192.2011.573966

Bentein, K., Vandenberghe, C., Vandenberg, R., \& Stinglhamber, F. (2005). The Role of Change in the Relationship between Commitment and Turnover: A Latent Growth Modeling Approach. Journal of Applied Psychology, 90(3), 468-482. https://doi.org/10.1037/0021-9010.90.3.468

Blau, P.M. (1964). Exchange and power in social life. New York: Wiley.

Boehm, S.A., Kunze, F., \& Bruch, H. (2014). Spotlight on age diversity climate: The impact of age-inclusive HR-practices on firm level outcomes. Personnel Psychology, 67(3), 667-704.

Borman, W.C., \& Motowidlo, S.J. (1997). Task performance and contextual performance: The meaning for personnel selection research. Human Performance, 10(2), 99-109.

Butler, R. (1969). Ageism: another form of bigotry. The Gerontologist, 9, 243-246.

Buttner, E.H., Lowe, K.B., \& Billings-Harris, L. (2012). An empirical test of diversity climate dimensionality and relative effects on employee of color outcomes. Journal of Business Ethics, 110, 247-258.

Cate, R.A., \& John, O.P. (2007). Testing models of the structure and development of future time perspective: Maintaining a focus on opportunities in middle age. Psychology and Aging, 22, 186-201.

Carr, J.Z., Schmidt, A.M., Ford, J.K., \& DeShon, R.P. (2003), Climate Perceptions Matter: A Meta- Analytic Path Analysis Relating Molar Climate, Cognitive and Affective States, and Individual Level Work Outcomes. Journal of Applied Psychology, 88(4), 605-619. https://doi.org/10.1037/0021-9010.88.4.605

Cleveland, J.N., \& McFarlane Shore, L.M. (1992). Self- and supervisory perspectives on age and work attitudes and performance. Journal of Applied Psychology, 77(4), 469-484. https://doi.org/10.1037/0021-9010.77.4.469

Cox, Jr., T., \& Nkomo, S.M. (1992). Candidate age as a factor in promotability ratings, Public Personnel Management, 21, 197-210. https://doi.org/10.1177/009102609202100207

Eisenberger, R. Huntington, R., Hutchison, S., \& Sowa, D. (1986). Perceived organizational support. Journal of Applied Psychology, 71, 500-507. https://doi.org/10.1037/0021-9010.71.3.500

European Commission. (2005). Communication from the Commission. Green paper Confronting demographic change: A new solidarity between the generations. Brussels, Belgium: Commission of the European Communities.

Finkelstein, L.M., Burke, M.J., \& Raju, M.S. (1995). Age discrimination in simulated employment contexts: An integrative analysis. Journal of Applied Psychology, 80(6), 652-663. 
Gaillard, M., \& Desmette, D. (2008). Intergroup predictors of older workers' attitudes towards work and early exit. European Journal of Work and Organizational Psychology, 17(4), 450-481.

Gelfand, M.J., Nishii, L.H., Raver, J., \& Schneider, B. (2005). Discrimination in organizations: An organizational level systems perspective. In R. Dipboye, \& A. Colella (Eds.), Discrimination at work: The psychological and organizational bases (pp. 89-116). Mahwah, NJ: Erlbaum.

Gonzalez, J.A., \& DeNisi, A.S. (2009). Cross-level effects of demography and diversity climate on organizational attachment and firm effectiveness. Journal of Organizational Behavior, 30, 21-40.

Gouldner, A.W. (1960). The norm of reciprocity: A preliminary statement. American Sociological Review, 25, 161-178. https://doi.org/10.2307/2092623

Greller, M.M., \& Simpson, P. (1999). In search of late career: A review of contemporary social science research applicable to the understanding of late career. Human Resource Management Review, 9, 309-347.

Griffiths, A. (1997). Ageing, health and productivity: A challenge for the new millennium. Work \& Stress, 11, 197-214. https://doi.org/10.1080/02678379708256835

Harrison, D.A, Newman, D.A., \& Roth, P.L. (2006). How Important are Job Attitudes? Meta-Analytic Comparisons of Integrative Behavioral Outcomes and Time Sequences. Academy of Management Journal, 49(2), 305-325.

Hassell, B.L., \& Perrewé, P.L. (1993). An examination of the relationship between older workers' perceptions of age discrimination and employee psychological states. Journal of Managerial Issues, 5(1), 109-120.

Hassell, B.L., \& Perrewé, P.L. (1995). An examination of beliefs about older workers: Do stereotypes still exist?. Journal of Organizational Behavior, 16(5), 457-468. https://doi.org/10.1002/job.4030160506

Hobfoll, S.E. (1989). Conservation of resources: A new attempt at conceptualizing stress. American Psychologist, 44(3), 513-524. https://doi.org/10.1037/0003-066X.44.3.513

Hobfoll, S.E. (2001). The influence of culture, community, and the nested-self in the stress process: advancing conservation of resources theory. Applied Psychology, 50(3), 337-421.

Hulland, J. (1999). Use of partial least squares (PLS) in strategic management research: a review of four recent studies. Strategic Management Journal, 20, 95-204.

Innocenti, L., Profili, S., \& Sammarra, A. (2013). Age as moderator in the relationship between HR development practices and employees' positive attitudes. Personnel Review, 42(6), 724-744.

James, L.A., \& James, L.R. (1989). Integrating work environment perceptions: Explorations into the measurement of meaning. Journal of Applied Psychology, 74(5), 739-751. https://doi.org/10.1037/0021-9010.74.5.739

Kaliterna, L., Larsen, Z.P., \& Brkljacic, T. (2002). Chronological and Subjective Age in Relation to Work Demands: Survey of Croatian Workers. Experimental Aging Research, 28(1), 39-49.

Kanfer, R., \& Ackerman, P. (2004). Aging, Adult Development, and Work Motivation. Academy of Management Review, 29, 440-458.

Konovsky, M.A., \& Pugh, S.D. (1994). Citizenship behaviour and social exchange. Academy of Management Journal, 37, 656-669. https://doi.org/10.2307/256704

Kooji, D.T.A.M., de Lange, A.H, Jansen, P.G.W., \& Dikkers, J.S.E. (2013). Beyond chronological age. Examining perceived future time and subjective health as age-related mediators in relation to work-related motivations and well-being, Work \& Stress, 27(1), 88-105. https://doi.org/10.1080/02678373.2013.769328

Kossek, E.E., \& Zonia, S.C. (1993). Assessing diversity climate: A field study of reactions to employer efforts to promote diversity. Journal of Organizational Behavior, 14, 61-81. https://doi.org/10.1002/job.4030140107

Kunze, F., Boehm, S.A., \& Bruch, H. (2011). Age diversity, age discrimination climate and performance consequences. A cross organizational study. Journal of Organizational Behavior, 32, 264-290.

Lambert, S.J. (2000). Added Benefits: The Link between Work-Life Benefits and Organizational Citizenship Behavior. The Academy of Management Journal, 43(5), 801-815. https://doi.org/10.2307/1556411

LePine, J.A., \& Van Dyne, L. (1998). Predicting voice behavior in work groups. Journal of Applied Psychology, 83, 853-868. https://doi.org/10.1037/0021-9010.83.6.853

LePine, J.A., \& Van Dyne, L. (2001). An attributional model of helping in the context of work groups. Academy of Management Review, 26, 67-84.

LePine, J.A., Erez, A., \& Johnson, D.E. (2002). The nature and dimensionality of organizational citizenship behavior: a critical review and meta-analysis. Journal of Applied Psychology, 87(1), 52-65. 
Loretto, W. \& White, P. (2006). Employers' attitudes, practices and policies towards older workers. Human Resource Management Journal, 16, 313-330. https://doi.org/10.1111/j.1748-8583.2006.00013.x

Mamman, A., Kamoche, K., \& Bakuwa, R. (2012). Diversity, organizational commitment and organizational citizenship behavior: An organizing framework. Human Resource Management Review, 22(4), 285-302.

Markus, H.R., \& Nurius, P. (1986). Possible selves. American Psychologist, 41(9), 954-969.

Mathieu, J.E., \& Zajac, D.M. (1990). A review and meta-analysis of the antecedents, correlates, and consequences of organizational commitment. Psychological Bulletin, 10 108(2), https://doi.org/10.1037/0033-2909.108.2.171

Maurer, T.J., \& Rafuse, N.E. (2001). Learning, not litigating: Managing employee development and avoiding claims of age discrimination. The Academy of Management Executive, 15(4), 110-121. https://doi.org/10.5465/AME.2001.5898395

Maurer, T.J., Weiss, E.M., \& Barbeite, F.G. (2003). A model of involvement in work-related learning and development activity: the effects of individual, situational, motivation, and age variables. Journal of Applied Psychology, 88, 707-724. https://doi.org/10.1037/0021-9010.88.4.707

McKay, P.F., Avery, D.R., \& Morris, M.A. (2009). A tale of two climates: Diversity climate from subordinates' and managers' perspectives and their role in store unit sales performance. Personnel Psychology, 62, 767-791.

McKay, P.F., Avery, D.R., Tonidandel, S., Morris, M.A., Hernandez, M., \& Hebl, M.R. (2007). Racial differences in employee retention: Are diversity climate perceptions the key?. Personnel Psychology, 60, 35-62.

Meyer, J.P., \& Allen, N.J. (1991). A three-component conceptualization of organizational commitment. Human Resource Management Review, 1(1), 61-89. https://doi.org/10.1016/1053-4822(91)90011-Z

Meyer, J.P., \& Allen, N.J. (1997). Commitment in the workplace. London: Sage.

Mor Barak, M.E., Cherin, D.A., \& Berkman, S. (1998). Organizational and personal dimensions in diversity climate: Ethnic and gender differences in employee perceptions. Journal of Applied Behavioral Science, 34, 82-104.

Mowday, R.T., Steers, R.M., \& Porter, L.W. (1979). The measurement of organizational commitment. Journal of Vocational Behavior, 14, 224-247. https://doi.org/10.1016/0001-8791(79)90072-1

Ng, T.W.H., \& Feldman, D.C (2008). The relationship of age to ten dimensions of job performance. Journal of Applied Psychology, 93(2), 392-423. https://doi.org/10.1037/0021-9010.93.2.392

OECD. (2006). Aging and Employement Policies. OECD. https://doi.org/10.1787/journal_dev-v6-sup1-en

Oettingen, G., \& Mayer, D. (2002). The motivating function of thinking about the future: Expectations versus fantasies. Journal of Personality and Social Psychology, 83, 1198-1212.

Organ, D.W. (1990). The motivational basis of organizational citizenship behaviour. Research in Organizational Behavior, 12(1), 43-72.

Organ, D.W., \& Konovsky, M.A. (1989). Cognitive versus affective determinants of organizational citizenship behaviour. Journal of Applied Psychology, 74, 157-164. https://doi.org/10.1037/0021-9010.74.1.157

Orpen, C. (1995). The effects of perceived age discrimination on employee job satisfaction, organizational commitment and job involvement. Psychology, 32, 55-56.

Parker, C.P., Baltes, B.B., Young, S.A., Huff, J.W., Altmann, R.A., LaCost, H.A., \& Roberts, J.E. (2003). Relationships between psychological climate perceptions and work outcomes: a meta-analytic review. Journal of Organizational Behavior, 24(4), 389-416. https://doi.org/10.1002/job.198

Peterson, C. (2000). The future of optimism. American Psychologist, 55, 44-55. https://doi.org/10.1037/0003-066X.55.1.44

Podsakoff, P.M., MacKenzie, S.B., \& Podsakoff, N.P. (2012). Sources of method bias in social science research and recommendations on how to control it. Annual Review of Psychology, 65, 539-569.

Podsakoff, P.M., MacKenzie, S.B., Moorman, R.H., \& Fetter, R. (1990). Transformational leader behaviors and their effects on followers' trust in leader, satisfaction, and organizational citizenship behaviors. The Leadership Quarterly, 1(2), 107-142. https://doi.org/10.1016/1048-9843(90)90009-7

Rabl, T., \& Triana, M. (2013). How German employees of different ages conserve resources: perceived age discrimination and affective organizational commitment. The International Journal of Human Resources Management, 24(19), 3599-3612. https://doi.org/10.1080/09585192.2013.777936

Redman, T., \& Snape, E. (2006). The Consequences of Perceived Age Discrimination Amongst Older Police 
Officers: Is Social Support a Buffer?. British Journal of Management, 17, 167-17.

Rhoades, L., \& Eisenberger, R. (2002). Perceived organizational support: a review of the literature. Journal of Applied Psychology, 87(4), 698-714. https://doi.org/10.1037/0021-9010.87.4.698

Roberson, L., \& Block, C.J. (2001). Racioethnicity and job performance: A review and critique of theoretical perspectives on the causes of group differences. Research in Organizational Behavior, 23, 247-325.

Rubin, B.A. \& Brody, C.J. (2005). Contradictions of commitment in the new economy: Insecurity, time, and technology. Social Science Research, 34(4), 843-861. https://doi.org/10.1016/j.ssresearch.2005.02.002

Rupp, D.E., Ganapathi, J., Aguilera, R.V., \& Williams, C.A. (2006). Employee reactions to corporate social responsibility: an organizational justice framework. Journal of Organizational Behavior, 27(4), 537-543.

Schneider, B., Ehrhart, M.G., \& Macey, W.H. (2011). Perspectives on organizational climate and culture, In S. Zedeck (Ed.), Handbook of industrial and organizational psychology (pp. 373-414). Washington, DC: American Psychological Association Press. https://doi.org/10.1037/12169-012

Schneider, B., Salvaggio, A.N., \& Subirats, M. (2002). Climate strength: a new direction for climate research. Journal of Applied Psychology, 87, 220-229. https://doi.org/10.1037/0021-9010.87.2.220

Settersten Jr, R. A., \& Mayer, K.U. (1997). The measurement of age, age structuring, and the life course. Annual Review of Sociology, 23, 233-261. https://doi.org/10.1146/annurev.soc.23.1.233

Shore, L.M., Barksdale, K., \& Shore, T.H. (1995). Managerial perceptions of employee commitment to the organization. Academy of Management Journal, 38(6), 1593-1615. https://doi.org/10.2307/256845

Shore, L.M., Chung-Herrera, B.G., Dean, M.A., Holcombe Ehrhart, K., Jung, D.I., Randel, A.E., \& Singh, G. (2009). Diversity in organizations: Where are we now and where are we going? Human Resource Management Review, 19(2), 117-133. https://doi.org/10.1016/j.hrmr.2008.10.004

Shore, L.M., Cleveland, J.N., \& Goldberg, C.B. (2003). Work attitudes and decisions as a function of manager age and employee age. Journal of Applied Psychology, 88(3), 529-537. https://doi.org/10.1037/0021-9010.88.3.529

Shore, L.M., Randel, A.E., Chung, B.E., Dean, M.A., Ehrhart, K.H., \& Sing, G. (2011). Inclusion and diversity in work groups: A review and model for future research. Journal of Management, 37, 1262-1289. https://doi.org/10.1177/0149206310385943

Snape, E., \& Redman, T. (2003). Too old or too young? The impact of perceived age discrimination. Human Resource Management Journal, 13, 78-89. https://doi.org/10.1111/j.1748-8583.2003.tb00085.x

Super, D.E. (1957). A life-span, life-space approach to career development. Journal of Vocational Behavior, 16(3), 282-298. https://doi.org/10.1016/0001-8791(80)90056-1

Van Auken, S., \& Barry, T.E. (2009). Assessing the nomological validity of a cognitive age segmentation of Japanese seniors. Asia Pacific Journal of Marketing and Logistics, 21(3), 315-328. https://doi.org/10.1108/13555850910973810

Van Dyne, L., Graham, J.W., \& Dienesch, R.M. (1994). Organizational Citizenship Behavior: Construct Redefinition, Measurement, and Validation. Academy of Management Journal, 37(4), 765-802. https://doi.org/10.2307/256600

Waldman, D.A., \& Avolio, B.J. (1986). A meta-analysis of age differences in job performance. Journal of Applied Psychology, 71(1), 33-38. https://doi.org/10.1037/0021-9010.71.1.33

Warr, P., \& Fay, D. (2001). Short Report: Age and personal initiative at work. European Journal of Work and Organizational Psychology, 10, 343-353. https://doi.org/10.1080/13594320143000717

Wayne, S. J., Shore, L. M., \& Liden, R.C. (1997). Perceived organizational support and leader- member exchange: A social exchange perspective. Academy of Management Journal, 40, 82-111. https://doi.org/10.2307/257021

Zacher, H., \& Frese, M. (2009). Remaining time and opportunities at work: Relationships between age, work characteristics, and occupational future time perspective. Psychology and Aging, 24(2), 487-493. https://doi.org/10.1037/a0015425

Zacher, H., Heusner, S., Schmitz, M., Zwierzanska, M.M., \& Frese, M. (2010). Focus on opportunities as a mediator of the relationships between age, job complexity, and work performance. Journal of Vocational Behavior, 76, 374-386. https://doi.org/10.1016/j.jvb.2009.09.001

Zohar, D. (2000). A group-level model of safety climate: testing the effect of group climate on microaccidents in manufacturing jobs. Journal of Applied Psychology, 85, 587-596. https://doi.org/10.1037/0021-9010.85.4.587 